\title{
PENGARUH BUDAYA UNIVERSITAS TERHADAP KINERJA MAHASISWA AKUNTANSI DENGAN KREATIVITAS SEBAGAI VARIABEL MODERASI (STUDI PADA MAHASISWA AKUNTANSI DI PERGURUAN TINGGI SE-KABUPATEN BULELENG)
}

\author{
Anantawikrama Tungga Atmadja \\ Universitas Pendidikan Ganesha \\ Komang Adi Kurniawan Saputra \\ Pusat Pendidikan dan Pelatihan Inata \\ anantawikramatunggaatmdja@gmail.com
}

\begin{abstract}
This research aimed to examine the influence of university culture on student performance with creativity variable as moderator. This research used survey method with questionnaire; the number of sample is 200 accounting students in North Bali, sampling technique used in this research is purposive sampling. Test of analysis used a simple regression test method and MRA (Moderated Regression Analysis). The results of this research indicate that the university culture has an effect on the performance of accounting students, and the variables of creativity moderate the influence of the university culture on student performance.
\end{abstract}

Keywords:

University culture; performance; creativity

Kualitas kehidupan sebuah universitas sangat tergantung pada spirit dan nilai-nilai yang melandasinya. Oleh karena itu, banyak pakar budaya pendidikan mendefinisikan kualitas universitas sebagai budaya yang dimiliki oleh universitas, tumbuh dan berkembang sesuai dengan spirit dan nilai-nilai yang dianutnya. Fakultas dalam sebuah universitas merupakan organisasi, sehingga budaya yang dianut fakultas kurang lebih sama dengan budaya universitas (Syarif dan Anggriyani, 2008). Kualitas kehidupan sebuah fakultas dalam universitas dapat ditampilkan dalam bentuk bagaimana dekan, dosen, dan mahasiswa serta pegawai lainnya bekerja, belajar dan berhubungan satu dengan lainnya, sebagaimana telah menjadi tradisi di universitas.

Peningkatan kualitas pendidikan harus dimulai dari meningkatkan mutu dosen, karena dosen merupakan ujung tombak operasional proses pendidikan di perguruan tinggi sehingga otomatis berimplikasi pada proses pencapaian kinerja mahasiswa. Penelitian Syarif dan Anggriyani (2008) menyatakan bahwa budaya universitas memiliki pengaruh terhadap kinerja dosen akuntansi di Medan, hasil tersebut secara langsung juga berimplikasi kepada proses pencapaian kinerja mahasiswa. Karena, kesuksesan mahasiswa dalam meraih tujuan belajarnya tergantung pada apa dan bagaimana dosen itu sendiri.

Hal seperti itu terjadi seiring dengan budaya fakultas yang mencerminkan budaya universitas dan telah menyita perhatian mahasiswa didalamnya. Perhatian ini terutama ditujukan dari sisi pelayanan terhadap mahasiswa, baik dari sisi proses belajar mengajar maupun dari sisi akademis lainnya. Berkaitan dengan hal tersebut, kreativitas mahasiswa diperlukan untuk memicu peningkatan kinerjanya. Mengingat saat ini Indonesia berada di jalur Masyarakat Ekonomi Asean (MEA) yang menyiapkan lulusan perguruan tinggi berkompetisi dengan pencari kerja asing.

Berdasarkan latar belakang diatas, maka penelitian ini bertujuan pengaruh budaya universitas terhadap proses pencapaian kinerja mahasiswa akuntansi yang dimoderasi oleh kreativitas. Penelitian ini dilakukan dengan maksud memberikan manfaat praktis untuk 
pengambilan kebijakan dan referensi keilmuan baik di bidang akuntansi keperilakuan maupun akuntansi sumber daya manusia.

\section{Signaling Theory}

Menurut Connelly, et al. (2011), signaling theory digunakan untuk mendeskripsikan perilaku dua pihak ketika mengakses informasi yang berbeda. Salah satu pihak yaitu pengirim informasi, harus memilih apa dan bagaimana mengkomunikasikan (atau mensinyalkan) informasi tersebut, dan pihak lain yaitu penerima informasi harus memilih bagaimana mengintrepretasikan sinyal tersebut. Connelly, et al. (2011) juga menjelaskan bahwa informasi berdampak pada proses pengambilan keputusan. Seseorang membuat keputusan berdasarkan informasi yang dipublikasikan secara bebas. Namun, adabeberapa informasi yang tidak dapat dipublikasikan (private). Oleh karena itu maka terjadi asimetri informasi antara pihak yang mempunyai informasi tersebut dan pihak yang berpotensi dapat membuat keputusan yang lebih baik jika memiliki informasi tersebut. Pada lingkup pendidikan tinggi hal ini dapat berarti bahwa informasi atau pengetahuan yang diterima mahasiswa akuntansi dari dosennya dapat mempengaruhi pengambilan keputusan mahasiswa kelak. Konsekuensi Indonesia sebagai salah satu peserta MEA berdampak pula pada profesi akuntan yang diperkirakan memiliki kompleksitas tugas yang tidak ringan. Untuk itu, sejak dini mahasiswa akuntansi harus mendapat informasi yang relevan tentang Standar Akuntansi terbaru, perkembangan ilmu akuntansi masa kini, model bisnis di era globalisasi dan lain sebagainya.

\section{Budaya Universitas}

Banyak konsep dan pendekatan yang digunakan untuk menjelaskan dan memberikan pengertian mengenai budaya. Menurut Hofstede (1994), budaya merupakan keseluruhan pola pikiran, perasaan dan tindakan dari suatu kelompok sosial yang membedakannya dengan kelompok sosial yang lain. Hofstede (1994) memberikan istilah the collective mental programming atau software of mind untuk menyebutkan keseluruhan pola tersebut. Mental programs atau budaya suatu kelompok terbentuk oleh lingkungan sosial (antara lain: negara, daerah, tempat kerja, sekolah, dan rumah tangga) dan kejadian-kejadian yang dialami dalam kehidupan para anggota kelompok yang bersangkutan.

Budaya organisasi meresap dalam kehidupan organisasi dan selanjutnya mempengaruhi setiap kehidupan organisasi. Oleh karena itu, budaya organisasi berpengaruh sangat besar pada aspek-aspek fundamental dari kinerja organisasi. Syarif dan Anggriyani (2008) menyatakan bahwa kualitas kehidupan organisasi, baik yang terwujud dalam kebiasaan maupun kepemimpinan dan hubungan tersebut tumbuh dan berkembang berdasarkan spirit dan keyakinan tertentu yang dianut organisasi.

\section{Kinerja Mahasiswa Akuntansi}

Kinerja atau kinerja berkaitan erat dengan tujuan, sebagai suatu hasil perilaku kerja seseorang. Perilaku kinerja dapat ditelusuri hingga ke faktor-faktor spesifik seperti kemampuan, upaya dan kesulitan tugas. Menurut Mangkunegara (2010:9), istilah kinerja berasal dari kata Job Kinerjance atau Actual Kinerjance (prestasi kerja atau prestasi sesungguhnya yang dicapai oleh seseorang). Pengertian kinerja (prestasi kerja) adalah hasil kerja secara kualitas dan kuantitas yang dicapai oleh seorang pegawai dalam melaksanakan tugasnya sesuai dengan tanggung jawab yang diberikan kepadanya.

Menurut Bernardin dan Russel (1993) dalam Kosasih dan Budiani (2007) terdapat enam kriteria untuk menilai kinerja, yaitu:

1. Quality, tingkatan dimana proses atau penyesuaian padacara yang ideal di dalam melakukan aktifitas ataumemenuhi aktifitas yang sesuai harapan.

2. Quantity, jumlah yang dihasilkan diwujudkan melalui nilai mata uang, jumlah unit, atau jumlah dari siklus aktifitas yang telah diselesaikan. 
3. Timeliness, tingkatan di mana aktifitas telah diselesaikan dengan waktu yang lebih cepat dari yang ditentukan dan memaksimalkan waktu yang ada untuk aktifitas lain.

4. Cost effectiveness, tingkatan dimana penggunaan sumber daya perusahaan berupa manusia, keuangan, dan teknologi dimaksimalkan untuk mendapatkan hasil yang tertinggi atau pengurangan kerugian dari tiap unit.

5. Need for supervision, tingkatan dimana seorang karyawan dapat melakukan pekerjaannya tanpa perlu meminta pertolongan atau bimbingan dari atasannya.

6. Interpersonal impact, tingkatan di mana seorang karyawan merasa percaya diri, punya keinginan yang baik, dan bekerja sama di antara rekan kerja.

Faktor penentu kinerja mahasiswa dapat dijelaskan dengan menggunakan pendekatan teori atribusi yang menyatakan bahwa dua kategori dasar atribusi yang melekat pada diri seorang mahasiswa yang akan menentukan kinerjanya, yaitu atribusi yang bersifat internal atau disposisional (dihubungkan dengan sifat-sifat orang), dan yang bersifat eksternal atau situasional (yang dapat dihubungkan dengan lingkungan seseorang (Bateman, 1984 dalam Maryani, 2010). Sumber internal seperti bakat, kemampuan, kemauan dan upaya. Sedangkan sumber eksternal terdiri atas lingkungan kampus, rekan mahasiswa, dan dosen. Kinerja mahasiswa dapat terjadi pada beberapa tingkatan, yaitu: individu, tim dan organisasi.

\section{Kreativitas}

Kreativitas dapat diartikan sebagai kemampuan seseorang untuk memecahkan masalah dan menemukan sesuatu yang baru. Kreativitas adalah kemampuan untuk menghasilkan pemikiran baru yang bermanfaat untuk bidang apapun. Kreativitas dapat dilihat dari aspek person (yakni produk atau keinginan) dan aspek proses (Cropley, et al, 2010). Proses kreatif secara alami mengandung nilai kebaikan ataupun keburukan (kejahatan). Seperti halnya sisi telapak tangan, satu sisi terang dan satu sisi gelap. Sisi gelap kreativitas hanyalah sebuah properti, motivasi dari manusia, atau penggunaan produk dan bukan kreativitas itu sendiri (Yulianto, Wiyantoro dan Retnowati, 2014). Penelitian Gino dan Ariely (2011) menyoroti sisi gelap dari kreativitas dan mengungkapkan hasil penelitian mengenai bukti hubungan antara kreativitas dan ketidakjujuran. Seseorang dengan pribadi kreatif yang mencetak tinggi pada tes pengukuran berpikir divergen cenderung lebih menipu. Kreativitas disposisional adalah prediktor yang lebih baik dari perilaku tidak etis. Peserta yang mempunyai kemampuan prima untuk berpikir kreatif lebih cenderung berperilaku tidak jujur karena motivasi kreativitas mereka dan kemampuan yang lebih besar untuk membenarkan perilaku tidak jujur mereka.

\section{Pengembangan Hipotesis}

\section{Pengaruh Budaya Universitas terhadap Kinerja Mahasiswa Akuntansi}

Gunawan (2009) yang menyatakan budaya organisasi yang dalam hal ini adalah budaya Tri Hita Karana berpengaruh signifikan terhadap kinerja. Selain itu, penelitian yang dilakukan oleh Maryani (2010), Usman (2007) dan Sulaksono (2005) yang menyatakan bahwa variabel budaya organisasi berpengaruh positif dan signifikan terhadap kinerja. begitu juga penelitian yang dilakukan oleh Lathifah dan Rustono (2015) menyatakan bahwa budaya organisasi berpengaruh signifikan terhadap kinerja. Namun, penelitian lainnya yang dilakukan oleh Trisnaningsih (2007) menyatakan bahwa tidak ada pengaruh yang signifikan antara budaya suatu organisasi dan kinerja karyawannya. Penelitian lainnya dari Saputra (2012) menyatakan bahwa budaya Bali Tri Hita Karana dapat diterapkan sebagai budaya organisasi untuk mendukung kontrol atau pengendalian diri para internal auditor karena terbukti mampu meningkatkan kinerja.

Serupa dengan penelitian di atas, pada penelitian ini budaya yang hendak diuji pengaruhnya terhadap kinerja mahasiswa adalah budaya universitas. Hasil penelitian budaya pada lingkup pendidikan tinggi dilakukan oleh Syarif dan Anggriani (2008). Hasilnya menyatakan bahwa budaya Universitas berpengaruh terhadap performance para dosen Universitas Negeri dan Swasta di Medan-Sumut. Semakin baik kultur Universitas yang dilaksanakan sehari-hari maka 
akan semakin baik pula performance dosen akuntansi dalam melaksanakan tugasnya. Perbedaannya, pada penelitian ini, kinerja yang hendak diukur adalah kinerja mahasiswa, sehingga hipotesis yang dikembangkan adalah:

$\mathrm{H}_{1}$ : Budaya universitas berpengaruh terhadap kinerja mahasiswa akuntansi

\section{Pengaruh Budaya Universitas terhadap Kinerja Mahasiswa Akuntansi yang dimoderasi oleh Kreativitas}

Budaya organisasi meresap dalam kehidupan organisasi dan selanjutnya mempengaruhi setiap kehidupan organisasi. Oleh karena itu, budaya organisasi berpengaruh sangat besar pada aspek-aspek fundamental dari kinerja organisasi. Pernyataan tersebut telah diterima dengan luas dan didukung oleh beberapa penelitian yang menghubungkan kinerja dengan budaya organisasi. Jika budaya organisasi merupakan aspek penting dalam meningkatkan kinerja maka budaya organisasi harus dikelola dengan baik(Triyono, 2013).

Budaya organisasi adalah keyakinan dan nilai bersama yang memberikan makna bagi anggota sebuah institusi dan menjadikan keyakinan dan nilai tersebut sebagai aturan/pedoman berperilaku di dalam organisasi. Hal tersebut menunjukkan bahwa budaya organisasi adalah kebiasaan yang berlaku pada sebuah organisasi. Bisa jadi, dengan demikian antara satu organisasi dengan organisasi lainnya mempunyai kebiasaan yang berbeda meski keduanya bergerak pada bidang aktivitas bisnis yang sama. Jadi secara operasional, budaya organisasi bermula dari individu bergabung dalam suatu kelompok dengan kebersamaannya mencipkan nilai dan aturan sebagai dasar berprilaku didalam organisasi (Peter dan Waterman (1992) dalam Triyono (2013)). Pengaruh kreativitas secara signifikan terhadap pendidikan akuntansi menunjukkan bahwa pendidikan akuntansi sarat dengan kreativitas. Seperti dalam penelitian yang dilakukan oleh Sabrin (2011) menyatakan bahwa kreativitas berpengaruh positif terhadap hasil belajar siswa akuntansi di Kendari. Salah satu kreativitas pada pendidikan akuntansi yaitu dengan adanya manajemen laba (earning manajemen) yang mengelola sisi aktiva (piutang, persediaan, aktiva tetap) yang terkait dengan laba. Selain itu, pendidikan akuntansi juga menunjukkan adanya pikiran, sikap, dan tindakan posistif, tindakan penuh dengan risiko yang ada, mengatasi tekanan, dorongan menerapkan regulasi menjadi lebih baik, adanya asumsi-asumsi dari pikiran dan tindakan, dan lainlaing (Hamzah, 2007).

Berdasarkan segala pernyataan dari beberapa hasil penelitian tentang budaya organisasi, kinerja dan kreativitas, maka hipotesis selanjutnya pada penelitian ini yaitu:

$\mathrm{H}_{2}$ : Budaya universitas berpengaruh terhadap kinerja mahasiswa akuntansi dengan kreativitas sebagai variabel pemoderasi

\section{METODE}

\section{Desain Penelitian}

Desain penelitian yang digunakan dalam penelitian ini adalah metode survei. Desain penelitian survei merupakan suatu perancangan penelitian dengan tujuan melakukan pengujian yang cermat dan teliti terhadap suatu obyek penelitian berdasarkan suatu situasi atau kondisi tertentu dengan melihat kesesuaiannya dengan pernyataan atau nilai tertentu yang diikuti dan diamati dengan cermat dan teliti (Atmadja, Darmawan dan Saputra (2015). Penelitian tentang pengaruh budaya universitas terhadap kinerja mahasiswa akuntansi dengan kreativitas sebagai variabel moderasi, dilakukan dengan cara survei kepada mahasiswa akuntansi seluruh perguruan tinggai baik negeri ataupun swasta di Kabupaten Buleleng.

\section{Populasi dan Teknik Pengambilan Sampel}

Populasi dalam penelitian ini adalah mahasiswa akuntansi di pergeruan tinggi negeri maupun swasta di Kabupaten Buleleng. Pemilihan mahasiswa akuntansi di Kabupaten Buleleng dimaksudkan untuk meningkatkan tingkat pengembalian kuesioner dan kuesioner dapat terkumpul tepat waktu untuk meminimalkan terjadinya respon bias. Alasan pemilihan Kabupaten Buleleng 
dimaksudkan untuk memudahkan konfirmasi dan evaluasi secara parsial terhadap budaya perguruan tinggi di Kabupaten Buleleng. Untuk itu teknik sampling yang digunakan dalam penelitian ini adalah purposive sampling. Untuk jumlah sampel yang digunakan dalam penelitian ini sebanyak 200 responden (mahasiswa yang tersebar di perguruan tinggi negeri dan swasta).

\section{Metode Pengumpulan Data}

Penelitian ini menggunakan data primer yang merupakan sumber data penelitian yang diperoleh secara langsung dari sumbernya (Indriantoro dan Supomo, 2009). Metode pengumpulan data dalam penelitian ini yaitu dengan teknik pengumpulan kuesioner. Total kusioner yang dikirim keseluruhan sampel adalah 200 kuesioner menggunakan mail questionnaires (kuesioner melalui pos/email) yang memungkinkan diperolehnya jawaban dari responden yang lokasinya terpencar (Indriantoro dan Supomo, 2009). Pada pelaksanaannya, dari 200 angket yang disebar terdapat beberapa kuesioner yang dikembalikan tidak sesuai seperti tidak dijawab, rusak dan tidak dikembalikan, jumlah kuesioner yang tidak dapat digunakan sebanyak 50 kuesioner, sehingga jumlah kuesioner yang dapat diolah selanjutnya sebanyak 150 kuesioner.

\section{Definisi Operasional Variabel \\ Budaya Universitas}

Variabel budaya universitas yang pada hakekatnya sama dengan budaya organisasi diukur menggunakan instrument penelitian milik Alindra (2015). Beberapa pertanyaan yang tersaji di angket penelitian Alindra (2015) digunakan kembali pada penelitian ini dengan modifikasi yang tidak merubah makna secara menyeluruh. Untuk penskoran dilakukan dengan cara memberi angka 5 pada pernyataan yang sangat mendukung, dan angka 1 untuk pernyataan yang tidak mendukung. Jumlah pertanyaan budaya sejumlah 29 item dengan menyertakan indikator inovasi dan pengambilan resiko, perhatian terhadap detail, orientasi hasil, orientasi individu, orientasi kelompok, serta agresivitas dan stabilitas

\section{Kinerja Mahasiswa Akuntansi}

Untuk mengukur kinerja mahasiswa akuntansi, penelitian ini menggunakan instrument yang dikembangkan oleh Alindra (2015) dengan melakukan berbagai penyesuaian. Indikator yang digunakan dalam variabel kinerja mahasiswa ini adalah (1) hasil kerja yang dirincikan menjadi kualitas dan kuantitas perkuliahan, serta efisiensi dalam melaksanakan tugas; (2) perilaku yaitu disiplin kuliah, inisiatif dan ketelitian; (3) sifat pribadi yang ada hubungannya dengan pekerjaan seperti kepemimpinan, kejujuran dan kreativitas. Intrumen penelitian dari Alindra (2015) memiliki beberapa indikator dengan menggunakan 5 alternatif jawaban. Untuk penskoran dilakukan dengan cara memberi angka 5 pada pernyataan yang sangat mendukung, dan selanjutnya angka 1 pada pernyataan yang tidak mendukung. Jumlah butir pertanyaan kinerja mahasiswa sebanyak 27 item.

\section{Kreativitas}

Untuk mengukur kreativitas, penelitian ini menggunakan instrumen yang dikembangkan oleh Idrus (2000) yang meneliti tentang kreativitas siswa di Yogyakarta. Intrumen penelitian untuk variabel kreativitas dalam penelitian ini memiliki maksud yang sama dengan penelitian sebelumnya. Untuk pengukurannya menggunakan angka 5 pada pernyataan yang sangat mendukung dan angka 1 untuk pernyataan yang tidak mendukung. Jumlah butir untuk mengukur kreativitas sebanyak 34 butir.

\section{Teknik Analisis Data}

Untuk menguji pengaruh budaya universitas terhadap kinerja mahasiswa akuntansi digunakan uji Regresi Linier Berganda, sedangkan pemoderasian kreativitas dilakukan dengan uji Moderated Regression Analysis (MRA). Sebelumnya dilakukan uji validitas dan reliabilitas atas 
instrumen yang digunakan. Penelitian ini melakukan pula uji asumsi klasik yang meliputi uji multikolinearitas, uji heteroskedastisitas, dan ujin ormalitas. Uji validitas menggunakan Pearson Correlation mengkorelasikan skor tiap butir pertanyaan dengan skor total yang merupakan jumlah korelasi. Variabel dikatakan valid apabila memiliki atau signifikansi lebih kecil dari 0,05, sedangkan variabel dikatakan reliabel jika memiliki nilai cronbach alpha lebih besar dari 0,70 (Ghozali,2011: 47-48). Uji normalitas dilakukan menggunakan Kolmogorov Smirnov dengankoefisien Asymp. Sig lebih besar dari 0,05 (Ghozali, 2011). Untuk mendeteksi adanya multikolinearitas digunakan nilai tolerance $=0,10$ dan Variance Inflation Factor (VIF) $=10$ (Ghozali, 2011). Pengujian heteroskedastisitas menggunakan uji Park, yaitu meregresikan nilai absolut residual dengan variabel bebas yang digunakan. Jika memiliki nilai signifikansi diatas 0,05 , dikatakan tidak terjadi heteroskedastisitas.

Untuk menguji hipotesis yang dilakukan dalam penelitian ini digunakan model analisis regresi berganda, dengan uji interaksi yang sering disebut Moderated Regression Analysis (MRA), yaitu aplikasi khusus regresi berganda linear di mana persamaan regresinya mengandung unsur interaksi (perkalian dua atau lebih variabel independen) dengan rumus persamaan sebagai berikut:

$\mathrm{KN}=\alpha+\beta_{1} \mathrm{BU}+\beta_{2} \mathrm{KR}+\beta_{3} \mathrm{BU} * \mathrm{KR}+\mathrm{e}$

Keterangan:

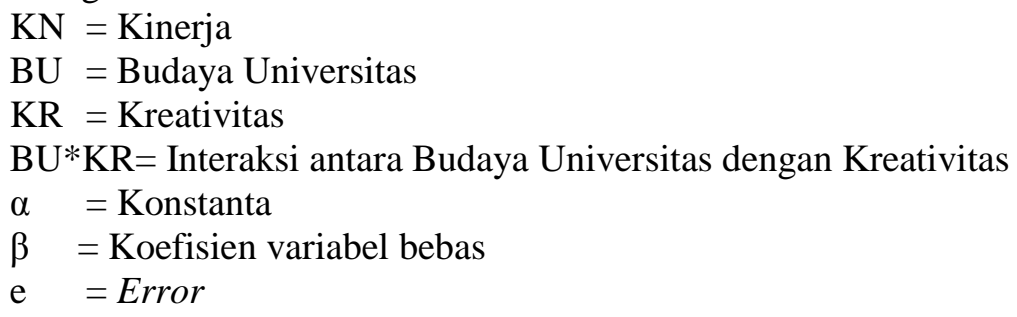

Pengujian terhadap hipotesis dengan menggunakan tingkat keyakinan 0.05 dan dilakukan dengan bantuan komputer SPSS. Model regresi di atas dengan bantuan program SPSS akan menghasilkan $\mathrm{R}^{2}$ yang menyatakan keeratan hubungan antar dua variabel yang diuji.

\section{HASIL DAN PEMBAHASAN}

Dalam penelitian ini dilakukan analisis data dari kuesioner yang kembali dan memenuhi syarat untuk diolah dengan bantuan SPSS sebanyak 150 kuesioner. Rincian responden yang berpartisipasi dalam pengisian kuesioner adalah berdasarkan jenis kelamin: laki-laki sebanyak 60 orang dan perempuan sebanyak 90 orang. Berdasarkan tingkatan semester; semester akhir sebanyak 20 orang, semester 6 sebanyak 80 orang, semester 4 sebanyak 30 orang, dan semester 2 sebanyak 20 orang. Hasil pengujian validitas dan reliabilitas instrumen menunjukkan bahwa instrumen yang digunakan dalam penelitian ini adalah valid dan reliabel, yang ditunjukkan dengan nilai koefisien korelasi item-total variabel lebih besar dari 0,3 dan signifikansi lebih kecil dari 0,05. Hasil uji reliabilitas menunjukkan nilai cronbach alpha untuk semua variabel yang digunakan dalam penelitian ini lebih besar dari 0,70 .

Hasil pengujian normalitas dengan uji One Sample Kolmogorov Smirnov Test menunjukkan hasil Asymp.Sig (2-tailed) sebesar 0,196 yang lebih tinggi dari 0,05 sehingga dikatakan data berdistribusi normal. Hasil perhitungan nilai tolerance menunjukkan semua variabel bebas memiliki nilai tolerance lebih dari 0,10 . Hasil perhitungan nilai VIF juga menunjukkan semua variabel bebas memiliki nilai VIF $<10$, atau tidak ada gejala multikolinieritas antar variabel bebas. Sedangkan, hasil uji heteroskedastisitas menunjukan bahwa semua variabel tidak signifikan pada 0.01 sehingga tidak terjadi heteroskedastisitas.

Berdasarkan hasil uji statistik dengan model regresi sederhana bahwa hipotesis null 1 ditolak. Hasil ini mengindikasikan bahwa budaya organisasi yang dalam penelitian ini diterjemahkan menjadi budaya universitas mempengaruhi kinerja mahasiswa akuntansi. Ini artinya bahwa, budaya atau kebiasaan yang telah membudaya dalam perguruan tinggi di Bali Utara telah 
berpengaruh terhadap hasil yang diraih mahasiswa akuntansi dalam perkuliahan. Jadi, apa yang sudah terjadi di kampus, baik dari hal kelembagaan sampai dengan dosen yang mengajar sangat berimplikasi kepada capaian mahasiswa akuntansi itu sendiri. Terlebih bahwa mata kuliah akuntansi sangatlah berpatokan dengan kondisi kekinian, sehingga dosen dalam hal ini harus update dengan praktik akuntansi saat ini. Informasi parktis dan teoritis yang didapat mahasiswa akuntansi nantinya akan direalisasikan dalam dunia kerja. Penelitian ini mendukung penelitian yang dilakukan oleh Syarif dan Anggriyani (2008) yang menyatakan bahwa kultur universitas berpengaruh terhadap kinerja dosen. Triyono (2013) yang menyatakan bahwa budaya organisasi mempengaruhi kepuasan dosen dan capaian mahasiswa. Penelitian lainnya yang memiliki hasil senada adalah penelitian yang dilakukan oleh Suhardi dan Devie (2015) yang menyatakan bahwa budaya universitas berpengaruh positif terhadap performa universitas itu sendiri.

Hasil uji statistik pada hipotesis kedua menyatakan bahwa kreativitas memoderasi hubungan budaya universitas terhadap kinerja mahasiswa akuntansi, maka dari itu dinyatakan bahwa hipotesis kedua diterima. Hasil ini mendukung penelitian dari Hamzah (2007) yang menyatakan bahwa kreativitas berpengaruh terhadap pendidikan akuntansi. Pengaruh kreativitas secara signifikan terhadappendidikan akuntansi menunjukkan bahwa pendidikan akuntansi sarat dengan kreativitas. Salah satu kreativitas pada pendidikan akuntansi yaitu dengan adanyamanajemen laba (earning manajemen) yang mengelola sisi aktiva (piutang, persediaan, aktiva tetap berhubungan dengan depresiasi) yang terkait dengan laba. Selain itu, pendidikan akuntansi juga menunjukkan adanya pikiran, sikap, dan tindakan posistif, tindakan penuh dengan risiko yang ada, mengatasi tekanan, mendorong membuat regulasi menjadi lebih baik, adanya asumsi-asumsi dari pikiran dan tindakan, sudah mulai menanggalkan logika, mengaitkan sesuatu hal dengan hal lain yang mampu membuat nilai tambah dan berdaya guna serta mampu memilah dan memilih bagia dari sesuatu untuk dibuat sesuatu yang berdaya guna dan bernilai tambah (Hamzah, 2007). Budaya universitas yang dimaksud dalam penelitian ini disetarakan dengan kurikulum yang berlaku karena budaya universitas dapat terlaksana berawal dari kurikulum yang diterapkan dalam sebuah program studi di perguruan tinggi. Penelitian lainnya dilakukan oleh Yulianto dan Wiyantoro (2010) yaitu mengindikasikan bahwa pengembangan kurikulum akuntansi berpengaruh terhadap kompetensi lulusan program studi akuntansi pada universitas di Indonesia. Pengembangan kurikulum akuntansi dapat mempengaruhi kompetensi kelulusan program studi akuntansi dengan menggunakan pengetahuan yang telah mereka peroleh dari tempat menuntut ilmu. Sehingga, maksud penelitian ini untuk program studi akuntansi adalah dapat meningkatnya kinerja mahasiswa yang diukur dengan meningkatnya indeks prestasi akademik, meningkatnya pemahaman praktis dan teoritis, meningkatnya kualitas lulusan program studi akuntansi, semakin baik kompetensi mahasiswa akuntasi agar mampu menjadi pribadi yang dapat menghadapi tantangan global, dapat menggunakan disiplin ilmu akuntansi dengan baik dalam memecahkan masalah, serta memiliki kreativitas yang baik seperti yang diharapkan oleh profesi akuntansi (Pricewaterhouse Coopers, 2003 dalam Yulianto dan Wiyantoro, 2010).

\section{SIMPULAN DAN SARAN}

Hasil penelitian menunjukkan budaya universitas memiliki pengaruh yang realistis terhadap capaian kinerja mahasiswa. Disamping itu, variabel kreativitas sebagai pemoderasi pengaruh budaya universitas terhadap kinerja mahasiswa ditunjukkan oleh diterimanya hipotesis kedua. Kreativitas memang sangat penting untuk menunjang kinerja mahasiswa akuntansi. Akuntansi merupakan jurusan yang dalam pembelajarannya sangat ditentukan oleh penyampaian informasi yang terkini sesuai dengan praktik dan regulasi yang ada sehingga kreativitas mahasiswa dalam hal menggali informasi secara mendalam dari setiap mata kuliah dan memperdalam pengetahuannya melalui bahan kuliah yang relevan.

Penelitian ini tidak terlepas dari keterbatasan dalam pelaksanaannya, berikut terdapat beberapa keterbatasan dalam penelitian ini antara lain: 
a. Penelitian ini memiliki keterbatasan yang melekat dikarenakan penelitian ini menggunakan data primer yang diperoleh melalui kuisioner, yaitu kemungkinan terjadi perbedaan persepsi antara peneliti dan responden karena tidak dapat saling mengklarifikasi pernyataan. Oleh karena itu penelitian tentunya menjadi lebih representatif apabila mengkombinasikan dengan metode wawancara sehingga persepsi responden atas pertanyaan atau pernyataan dapat diketahui secara mendalam

b. Penelitian ini hanya menggunakan sampel mahasiswa di Bali Utara, sehingga tidak cukup mewakili mahasiswa akuntansi pada umumnya.

c. Penelitian ini hanya mengungkapkan budaya universitas, kinerja mahasiswa akuntansi dan kreativitas. Masih terdapat serangkaian variabel yang dapat dikembangkan dalam penelitian ini seperti misalnya minat mahasiswa, motivasi, sistem pembelajaran dan etika. Penelitian selanjutnya disarankan mempertimbangkan variabel-variabel tersebut.

\section{DAFTAR RUJUKAN}

Alindra. Aput Ivan. (2015). Analisis Pengaruh Budaya Organisasi terhadap Kinerja Karyawan Depok Sports Center. Skripsi, Universitas Negeri Yogyakarta.

Atmadja, Anantawikrama T, Ari Surya D dan K.A. Kurniawan Saputra. (2015). Pengaruh Implementasi Good Corporate Governance dan Proteksi Awig-Awig Terhadap Kinerja Lembaga Perkreditan Desa (LPD) Dengan Budaya Menyama Braya Sebagai Variabel Moderasi (Studi Pada LPD Se-Kabupaten Buleleng). Konferensi Regional Akuntansi II, tahun 20015, Universitas Kanjuruhan Malang.

Connelly, B.L., Certo, S.T., Ireland, R.D. \& Reutzel, C.R. (2011). Signaling Theory: A Review and Assessment. Journal of Management, 37(1), 39-67.

Cropley, D. H., Cropley, A. J., Kaufman, J. C., \& Runco, M. A. (2010). The Dark Side of Creativity. New York: Cambridge University Press.

Ghozali, Imam. (2009). Ekonometrika: Teori, Konsep dan Aplikasi dengan SPSS 17. Badan Penerbit Universitas Diponegoro. Semarang.

Gino, F and Ariely, Dan. 200. The Dark Side of Creativity: Original Thinkers Can be More Dishonest.Working Paper.Harvard Bussiness School

Gunawan, Ketut. (2009). Pengaruh Budaya Organisasi, Kepuasan Kerja dan Motivasi Kerja terhadap Gaya Kepemimpinan dan Kinerja Organisasi (Studi pada Lembaga Perkreditan Desa (LPD) di Bali). Disertasi Program Pascasarjana Universitas Brawijaya, Malang.

Hamzah, Ardi. (2007). Pengaruh Sosiologi Kritis, Kreativitas, Dan Mentalitas Terhadap Pendidikan Akuntansi. Simposium Nasional Akuntansi X, Universitas Hasanudin, Makasar.

Hofstede, G. (1994). Cultures and Organization: Software of the Mind Intercultural Cooperation and its Importancefor Survival, NY: Harper Collins PublisherInc.

Idrus, Muhamad. (2000). Kreativitas Siswa SMP di Kota Yogyakarta. Lembaga Penelitan Universitas Islam Yogyakarta.

Indriantoro, Nur dan Bambang Supomo. (2009). Metode Penelitian Bisnis (Untuk Akuntansi dan Manajemen). BPFE Yogyakarta.

Kosasih, Natalia dan Sri Budiani. (2007). Pengaruh Knowledge Management Terhadap Kinerja Karyawan: Studi Kasus Departemen Front Office Surabaya Plaza Hotel. Jurnal Manajemen Perhotelan. Vol.3. No.2 pp 80-88.

Latifah, Atsti Fauzia Ulfana dan Anthon Rustono. (2015). Pengaruh Budaya Organisasi Terhadap Kinerja Karyawan Madrasah Aliyah Negeri (MAN) Cimahi. Prodi S1 Manajemen Bisnis Telekomunikasi dan Informatika, Fakultas Ekonomi dan Bisnis, Universitas Telkom.

Mangkunegara, A.P. (2010), "Evaluasi Kinerja SDM”. Cetakan Pertama. PT. Refika Aditama, Bandung. 
Maryani. (2010). Pengaruh Budaya Organisasi dan Gaya Kepemimpinan Serta Pengembangan Karyawan Terhadap Kepuasan Kerja dan Kinerja Karyawan pada Perusahaan Ritel di Sulawesi Selatan. Disertasi Program Pascasarjana Universitas Brawijaya, Malang.

Sabrin. (2011). Hubungan Antara Kreativitas Siswa dengan Hasil Belajar Akuntansi Siswa Kelas XI SMK Negeri 1 Kendari. Selami IPS, Edisi Nomor 34 Volume 1 Tahun XVI Desember.

Saputra, K. Adi Kurniawan. (2012). Analisis Pengaruh Locus Of Control Terhadap Kinerja dan Kepuasan Kerja Internal Auditor dengan Kultur Lokal Tri HitaKarana Sebagai Variabel Moderasi (Penelitian Terhadap Internal Auditor Hotel Berbintang di Bali). Jurnal Akuntansi Multiparadigma, Vol.3 No.1, April.

Suhardi, Utamo dan Devie. (2015). Pengaruh Budaya Universitas terhadap Performa Universitas Melalui Orientasi Kewirausahaan dan Pemberdayaan Sebagai Variabel Intervening. Business Accounting Review, Vol. 3, No. 1, Januari 2015: 410-421.

Sulaksono, Tri. (2005). Budaya Organisasi Dan Ketidakpastian Lingkungan Sebagai Variabel Moderating Dalam Hubungan Antara Gaya Evaluasi Atasan Terhadap Tekanan Kerja Dan Kepuasan Kerja Bawahan (Studi pada PT. Bank Perkreditan Rakyat Wilayah Kantor BI Solo). Tesis Program Pascasarjan Universitas Diponegoro.

Syarif, Firman dan Anggriyani. (2008). Pengaruh Pandangan Dosen Akuntansi Tentang Kepemimpinan Dekan dan Kultur Universitas Terhadap Performance Dosen Akuntansi di beberapa Universitas Negeri dan Swasta di Sumut (Studi Kasus di SUMUT) Medan. Simposium Nasional Akuntansi XI, Universitas Tanjungpura, Pontianak.

Trisnaningsih, Sri. (2007). Independensi Auditor dan Komitmen Organisasi Sebagai Mediasi Pengaruh Pemahaman Good Governance, Gaya Kepemimpinan dan Budaya Organisasi Terhadap Kinerja Auditor. Simposium Nasional Akuntansi X, Universitas Hasanudin, Makasar.

Triyono. (2013). Budaya Organisasi (Studi Eksplorasi Pada Universitas Muhammadiyah Semarang). Value Added, Vol. 9, No.1, September 2012 - Pebruari 2013. http://jurnal.unimus.ac.id

Usman, Umedi. (2007). Pengaruh Budaya Organisasi dan Motivasi terhadap Kepuasan Kerja dan Kinerja Karyawan pada Perusahaan Rokok di Jawa Timur. Disertasi Program Pascasarjana Universitas Brawijaya, Malang.

Yulianto, Agus Sholikhan dan Lili Sugeng Wiyantoro. (2010). Kajian Tentang Pengaruh Pengembangan Kurikulum Akuntansi Terhadap Kompetensi Lulusan Program Studi Akuntansi (Penelitian Pada Auditor Junior Kantor Akuntan Publik Di Jakarta). Simposium Nasional Akuntansi XIII, Universitas Jendral Sudirman, Purwokerto.

Yulianto, Agus Sholikhan, Lili Sugeng Wiyantoro dan Wulan Retnowati. (2014). Accounting Fraud dalam Perspektif Gender dan Kreativitas: Marital Status dan Pertemanan Sebagai Variabel Moderating (Survey pada Pegawai Direktorat Jenderal Pajak Republik Indonesia: Direktorat Keberatan \& Banding dan Direktorat Intelijen di Jakarta). Simposium Nasional Akuntansi XVII, Universitas Mataram, Lombok. 